\title{
Analysis of radiation induced hydrocarbons by electron-beam irradiation in dried squid (Todarodes pacificus) and octopus (Paroctopus dofleini)
}

\author{
Young Shin Hong, Keun Young Ryu, Kyong Su Kim* \\ Department of Food and Nutrition, Chosun University, Gwangju 501-759, Korea
}

\section{전자선 조사한 건조된 오징어와 문어에서 유도된 지방분해산물의 분석}

\author{
홍영신 · 류근영 · 김경수* \\ 조선대학교 식품영양학과
}

\begin{abstract}
Food irradiation is one of the successful modem techniques used to preserve food. However, it needs very careful control. Detection of irradiated food is of prime importance to facilitate global trade and consumer assurance, choice, and protection. This study was performed to evaluate the radiation-induced hydrocarbon content of dried squid and octopus by e-beam inadiation. The samples were collected from supermarkets all over South Korea and irradiated with an e-beam at $0,1,3,5,7$, and $10 \mathrm{kGy}$ doses. Lipids were extracted with soxhelt, and the hydrocarbons induced with imadiation were separated via solid phase extraction (SPE) and identified via gas chromatography mass spectrometry (GC/MS). The major induced hydrocarbons in the irradiated dried squid and octopus were 1-tetradecene and pentadecane derived from palmitic acid and 1-hexadecene and heptadecane from stearic acid. The concentration of hydrocarbons differed from the composition of the fatty acid at the same radiation and increased according to the level of the radiation dose. The hydrocarbons induced by e-beam irradiation, including 1-tetradecene, 1-hexadecene, and heptadecane, were confimed to have been the irradiation marker compounds. Therefore, they can be used to distinguish the e-beam-irradiated dried squid and octopus from the non-irradiated ones.
\end{abstract}

Key words : GC/MS, dried squid, dried octopus, e-beam, hydrocarbons

\section{서 론}

오징어(Todarodes pacificus)와 문어(Paroctopus dofleini) 는 색다른 조직감과 풍미가 있어 오래전부터 기호성이 높은 전통 식품으로 생체 유리아미노산인 타우린(Taurine)이 일 반 어류보다 높게 함유되어 있다(1). 타우린은 $\mathrm{ACE}$ (Angiotensin I Converting Enzyme) 활성 저해와 NO(Nitric oxide)의 생성을 억제하고 체내 LDL(Low Density Lipoprotein) cholesterol를 저하시키고 HDL(High Density Lipoprotein) cholesterol를 증가시키며, 면역증강작용 및 해 독작용 등을 갖는 기능성 성분으로 알려져 있다(2-5).

오징어와 문어를 포함한 수산물의 가공품 종류는 냉동

*Corresponding author. E-mail : kskim@chosun.ac.kr

Phone : 82-62-230-7724, Fax : 82-62-224-8880
품, 염장품, 자건품, 소건품, 조미가공품 및 젓갈류 등이 있으며, 그 중 가장 많이 이용되고 있는 가공품은 냉동품으 로 단순히 원료 저장을 목적으로 이용된다(6). 소건품인 오징어와 문어는 어획물의 단순 저장 수단으로 주로 천일건 조법을 이용하고 있어 가공 및 유통 과정이 낙후되어 저장 및 진열 과정 중 산화와 갈변현상으로 품질이 저하되며, 세균, 효모, 곰팡이 등에 의한 오염으로 변질 및 변패 가능성 이 높아 식중독의 잠재적인 위험성이 크다(7).

건조 수산물은 사전 처리를 하지 않고 요리를 하거나 날것으로 그대로 먹기 때문에 미생물에 오염된 경우는 식중 독 유발 가능성이 높은 원인 식품으로 지적되고 있다(8). 이런 문제점들을 최소화 하기 위하여 비가열처리인 방사선 조사 처리가 식품에 많이 이용되고 있다(9). 식품에 대한 방사선 조사 허가국은 56 개국으로 수산물은 27 개국이고 그 중 17 개국은 수산물에 대해 제한없이 조사가 이루어지 
고 7개국은 갑각류나 냉동수산물로 한정되며, 인도네시아, 태국, 쿠바는 살충을 목적으로 건조수산물까지 허용되어 있다. 국내에서 수산물에 대한 방사선 조사는 건 어류 분말 에 한정되어 미생물 통제를 위하여 최대 $7 \mathrm{kGy}$ 선량까지 조사가 허가되어 있다(10).

방사선 조사는 과일의 숙도조절, 곡류의 발아억제 및 살 충, 병원성 미생물 살균을 목적으로 1921년 처음 미국에서 시작되어 1950년부터 식품에 많이 이용되어 왔다. 식품에 조사가능한 방사선의 종류는 감마선, 전자선(10 Mev 이하), $\mathrm{X}$ 선이 있으며, FAO(Food and Agriculture Organization of the United Nations), WHO(World Health Organization), IAEA(International Atomic Energy Agency), CODEX(Codex Alimentarius Commission) 등에서 허용된 조사선량은 최대 $10 \mathrm{kGy}$ 까지로 조사식품의 안정성이 확인되었다(11-13).

전자선은 감마선과 $\mathrm{X}$ 선에 비해서 투과도가 낮으나 조사 선량 조절이 쉬우며 짧은 처리시간으로 대량의 제품을 연속 적으로 처리할 수 있고 조사시 기계적 장치에서 발생하는 에너지를 이용하고 방사성물질을 사용하지 않기 때문에 감마선에 비해 소비자에게 좋은 인식을 주는 등 많은 이점 이 있어 2000년 이후 미국, EU, 캐나다, 영국 등의 주요 선진국에서 전자선 이용률이 증가하고 있다(14). 국내에서 도 2012년 식품의약품안전청의 ‘식품의 기준 및 규격' 개정 안에서 식품조사처리 선종으로 전자선이 추가되었다(15).

전자선에 관한 연구로 Shim 등(16)과 Hong 등(17)은 캠벨 얼리 포도, 동결건조 김치분말 등에 전자선를 조사하여 휘 발성 유기성분 변화에 대해 보고하였으며, Ko 등(18)과 Jung 등(19)은 전자선 조사된 통후추 분말과 시판선식, 명란 젓갈의 미생물학적 안전성에 대해 보고하였다. 또한 Ko 등(20)은 건조 오징어에 전자선을 조사하여 미생물학적 안 전성을 확인하였으며, 색도의 변화 및 냄새, 맛 등 기호도에 유의적인 차이가 없는 것으로 보고한 바 있다.

위와 같이 전자선 조사에 관한 연구가 활발히 진행되고 있는데 건오징어와 건문어의 조사여부 확인을 위한 연구가 미비한 실정이다. 따라서 본 연구는 건조된 오징어와 문어 의 전자선 조사시 유도 생성되는 hydrocarbon류를 동정하 고 그 양을 비교 - 분석 하여 전자선 조사여부 판별 marker로 활용하고자 한다.

\section{재료 및 방법}

재 료

본 실험에 사용한 시료는 건조된 오징어와 문어를 광주 지역 재래시장에서 구입한 후 한국원자력연구소 내 전자선 조사시설 electron-beam accelerator(Model ELV-4, $2.5 \mathrm{MeV}$, EB-Tech., Ltd., Daejeon, Korea)를 이용하여 low density polyethylene(LDPE) bag에 시료의 크기가 $60 \mathrm{~mm}$ (length) $\times 60 \mathrm{~mm}$ (width)가 되도록 진공 포장한 후 가속 전류 2 8 $\mathrm{mA}$, beam dimension $600 \mathrm{~mm}$ (length) $\times 600 \mathrm{~mm}$ (width), velocity $5 \sim 10 \mathrm{~m} / \mathrm{min}$ 의 선량률로 총 흡수선량이 $1,3,5$, 7 및 $10 \mathrm{kGy}$ 가 되도록 조사하였다. 이 때의 흡수선량은 cellulose triacetate(CTA) dosimeter로 확인하였다. 조사된 시료들은 비조사 대조시료와 함께 $-18^{\circ} \mathrm{C}$ 로 냉동 저장하면 서 실험에 사용하였다.

시 약

본 실험에 사용한 모든 시약 및 지방분해산물인 hydrocarbon류의 standard는 미국 Sigma(St. Louis, MO, USA)사와 독일 TeLA(Karlsruhe, Germany)사로부터 구입 하였으며, 지방추출 및 chromatography에 사용한 n-hexane 등 유기용매는 HPLC grade용으로 구입하여, 이를 다시 wire spiral packed double distilling(Normschliff Geratebau, Germany) 장치로 재증류한 것을 사용하였다. Florisil(60 100 mesh)은 Fisher Scientific(Waltham, MA, USA) 제품을 구입하여 $550^{\circ} \mathrm{C}$ 회화로에서 하롯저녁 태운 뒤 desiccator에 서 방냉한 후, hydrocarbon류를 분리하기 위하여 $3 \%$ 물을 가한 후 20 분 동안 균질화하고 12 시간 이상 방치 후 불활성 화시켜 충진제로 사용하였다.

\section{지방추출}

조사선량별 시료 $5 \mathrm{~g}$ 과 $\mathrm{Na}_{2} \mathrm{SO}_{4}$ 를 혼합하여 다공성 thimble에 넣고 soxtec HT2(Foss, Nanterre, Seine, France) 장치에서 약 $50 \mathrm{~mL}$ 의 추출용매 n-hexane을 extraction cup에 가하고 extraction unit에 넣어서 지방을 추출하였다. 지방추 출은 rinsing 및 boiling 단계를 자동으로 하게 하고, solvent recovery까지 $45 \mathrm{~min}$ 이 소요되었다. 추출용액은 rotary vacuum evaporator(Büchi, Flawil, Switzerland)와 $\mathrm{N}_{2}$ gas 를 이용하여 용매를 제거한 후 냉동저장하여 실험 시료로 사용 하였다.

\section{지방산 조성 분석}

건오징어와 문어의 추출된 조지방을 Metcalf 등(21)의 방법에 따라 $1 \mathrm{~N} \mathrm{KOH} / \mathrm{EtOH}$ 로 검화한 후 $14 \% \mathrm{BF}_{3}-\mathrm{MeOH}$ 에 의한 methlyester화 후 $\mathrm{GC}($ Varian star $3400 \mathrm{CX}$, Varian, Santa Clara, CA, USA)로 분석하였다. Column은 DB-FFAP 122-3232(30 m×0.25 mm I.D., $0.25 \mu \mathrm{m}$ film; J\&W Scientific, Folosm, CA)를 사용하였고 carrier gas는 $\mathrm{N}_{2}$ 를 사용하였으 며, injector와 detector의 온도는 각각 $240^{\circ} \mathrm{C}$ 와 $250^{\circ} \mathrm{C}$ 로 하였 다. Temperature program은 $150^{\circ} \mathrm{C}(2 \mathrm{~min})$ 에서 $180^{\circ} \mathrm{C}(5 \mathrm{~min})$ 까지 $5^{\circ} \mathrm{C} / \mathrm{min}$ 으로 승온시킨 후 $8^{\circ} \mathrm{C} / \mathrm{min}$ 으로 $240^{\circ} \mathrm{C}(29.5 \mathrm{~min})$ 로 하였다. 시료는 split ratio $1: 20$ 으로 하여 $1 \mu \mathrm{L}$ 를 주입하였 다. $\mathrm{GC}$ 에서 분석된 각 지방산의 peak 확인은 standard의 relative retention time을 기준으로 하였고 지방산들의 조성 비를 백분율(\%)로 표시하였다. 
Hydrocarbon류의 분리

불활성화시킨 florisil $25 \mathrm{~g}$ 을 $200 \times 20 \mathrm{~mm}$ chromatography column에 충진한 후, 추출한 지방 $1 \mathrm{~g}$ 에 정량분석을 위해 I.S(internal standard)로서 $1 \mathrm{~mL}$ n-eicosane $(4 \mathrm{\mu g} / \mathrm{mL}$ n-hexane) 을 첨가하여 column에 가한 뒤 $60 \mathrm{~mL} \mathrm{n}$-hexane을 용리용매 로하여 hydrocarbon류를 분리하였다. 이 용리용매는 335 $\mathrm{mBar}$ 와 $40^{\circ} \mathrm{C}$ 조건하에서 rotary vacuum evaporator를 이용 하여 $2 \mathrm{~mL}$ 까지 농축한 후 이를 $0.5 \mathrm{~mL}$ 까지 질소로 농축하 여 $\mathrm{GC} / \mathrm{MS}$ 를 이용하여 분석하였다(22).

\section{Hydrocarbon류의 GC/MS 분석}

분리된 hydrocarbon류는 $\mathrm{GC} / \mathrm{MS}(\mathrm{QP}-5050$, Shimadzu, Tokyo, Japan)를 사용하였으며 시료의 이온화는 electron impact ionization(EI) 방법으로 행하였다. GC/MS 분석조건 은 ionization 전압은 $70 \mathrm{eV}$ 로 하였고 injector와 ion source 온도는 각각 $250^{\circ} \mathrm{C}$ 로 하였다. carrier gas는 helium, 유속은 $1.0 \mathrm{~mL} / \mathrm{min}$ 로 설정하였다. 또한 분자량의 범위는 $40-$ $350(\mathrm{~m} / \mathrm{z})$ 으로 설정하였다. Capillary column은 DB-5(0.32 $\mathrm{mm}$ i.d $\times 30 \mathrm{~m} \mathrm{~L} ., 0.25 \mu \mathrm{m}, \mathrm{J} \& \mathrm{~W}$ Scientific)를 이용하였다. Temperature program은 $60^{\circ} \mathrm{C}$ 에서 $170^{\circ} \mathrm{C}$ 까지 $25^{\circ} \mathrm{C} / \mathrm{min}$ 속도 로, $205^{\circ} \mathrm{C}$ 까지 $2^{\circ} \mathrm{C} / \mathrm{min}$ 속도로 승온시키고, 다시 $270^{\circ} \mathrm{C}$ 까지 $10^{\circ} \mathrm{C} / \mathrm{min}$ 속도로 승온시켰다. Hydrocarbon류 분석을 위해 서는 시료 $1 \mu \mathrm{L}$ 를 주입하고 split ratio는 1:20으로 하였으며, 초기 2분 동안은 splitless 조건으로 하였다(23).

\section{결과 및 고찰}

건조된 오징어와 문어의 주요지방산 조성은 Table 1 에 나타낸 것과 같이 palmitic $\operatorname{acid}(\mathrm{C} 16: 0)$, palmitoleic acid $\left(\mathrm{C}_{16: 1}\right)$, stearic $\operatorname{acid}\left(\mathrm{C}_{18: 0}\right), \operatorname{EPA}\left(\mathrm{C}_{20: 5}\right)$ 및 $\mathrm{DHA}\left(\mathrm{C}_{22: 6}\right)$ 가 함유 되어 있었다. 그 중에 포화지방산인 palmitic acid는 각각 $55.1 \%$ 및 $30.1 \%$ 로 건조된 오징어가 문어보다 많은 함량을 나타내었고, stearic acid 또한 $22.7 \%, 18.2 \%$ 로 건오징어에 좀 더 많은 함유량을 보였다. 건오징어의 포화지방산 함량 은 $77.8 \%$ 이며 불포화지방산은 $22.2 \%$ 로 확인되었다. 건문 어의 포화지방산은 $54.4 \%$ 로 건오징어보다 적은 함량을 나 타내었고 불포화지방산은 $45.6 \%$ 로 많은 함량을 나타내었 다. 이러한 지방산에 전자선을 조사시키면 중성지방의 carbonyl group의 $\alpha$ 탄소와 $\beta$ 탄소위치의 결합이 끊어져 모지 방산보다 탄소수가 1 개 $\left(\mathrm{C}_{\mathrm{n}-1}\right)$ 적거나, 2 개 $\left(\mathrm{C}_{\mathrm{n}-2}\right)$ 적으면서 첫 번째 탄소위치에 새로운 이중결합을 가진 hydrocarbon류가 생성된다(24). 즉 palmitic acid로부터 pentadecane $\left(\mathrm{C}_{15: 0}\right)$, 1-tetradecene $\left(\mathrm{C}_{14: 1}\right)$, stearic acid로부터 heptadecane $\left(\mathrm{C}_{17: 0}\right)$, 1-hexadecene $\left(\mathrm{C}_{16: 1}\right)$, oleic acid로부터 8-heptadecene $\left(\mathrm{C}_{17: 1}\right)$, 1,7-hexadecadiene $\left(\mathrm{C}_{16: 2}\right)$, linoleic acid로부터 6,9-heptadecadiene $\left(\mathrm{C}_{17: 2}\right), 1,7,10$-hexadecatriene $\left(\mathrm{C}_{16: 3}\right)$ 이 생성된다. 건오징어와
건문어의 지방산 중 $\mathrm{EPA}$ 와 $\mathrm{DHA}$ 로부터 생성되어지는 hydrocarbon류는 표준물질(standard material)의 부재로 동 정할 수 없었다. Linoleic acid와 oleic acid로부터 유도되는 hydrocarbon류는 거의 나타나지 않아 그 지방산 함량이 낮 기 때문이라고 사료되어 본 연구에서는 전자선 조사 검지를 위한 marker로서 큰 의미를 갖지 못 할 것으로 판단되어 그 분석결과를 나타내지 않았다. 이에 반해 건오징어와 건 문어에 다량 함유된 palmitic acid와 stearic acid로부터 유도 생성되어지는 hydrocabon류는 전자선 조사여부를 판단 할 수 있는 지표로 이용 가능한 것으로 확인되었다.

Table 1. Fatty acids compositions of dried squid and octopus

\begin{tabular}{lcc}
\multicolumn{1}{c}{ Fatty acid } & Dried squid & Dried octopus \\
\hline Lauric acid $\left(\mathrm{C}_{12: 0}\right)$ & $\mathrm{ND}^{1)}$ & 6.1 \\
Myristic acid $\left(\mathrm{C}_{14: 0}\right)$ & $\mathrm{ND}$ & $\mathrm{ND}$ \\
Palmitic acid $\left(\mathrm{C}_{16: 0}\right)$ & 55.1 & 30.1 \\
Palmitoleic acid($\left(\mathrm{C}_{16: 1}\right)$ & $\mathrm{ND}$ & 16.3 \\
Stearic acid $\left(\mathrm{C}_{18: 0}\right)$ & 22.7 & 18.2 \\
Oleic acid $\left(\mathrm{C}_{18: 1}\right)$ & 0.5 & $\mathrm{ND}$ \\
Linoleic acid($\left(\mathrm{C}_{18: 2}\right)$ & $\mathrm{ND}$ & $\mathrm{ND}$ \\
Eicosenoic acid$\left(\mathrm{C}_{20: 1}\right)$ & $\mathrm{ND}$ & $\mathrm{ND}$ \\
Eicosapentaenoic acid$\left(\mathrm{C}_{20: 5}\right)$ & 12.1 & 3.2 \\
Docosahexaenoic acid$\left(\mathrm{C}_{22: 6}\right)$ & 9.6 & 26.1 \\
Total & 100 & 100 \\
\hline TSFA & 77.8 & 54.4 \\
TUSFA & 22.2 & 45.6 \\
\hline
\end{tabular}

${ }^{1)} \mathrm{ND}$ : Not detected

${ }^{2)}$ Total saturated fatty acid

${ }^{3)}$ Total unsaturated fatty acid

전자선 조사된 건오징어에서 생성된 hydrocarbon 류

전자선 조사된 건오징어에서 생성된 hydrocarbon류를 $\mathrm{SPE}$ 방법으로 분리한 후 $\mathrm{GC} / \mathrm{MS}$ 로 분석하여 비조사 시료 및 $10 \mathrm{kGy}$ 선량으로 조사된 시료에서 유도된 hydrocarbon 류의 chromatogram을 Fig. 1에 나타내었고 조사선량에 따른 생성량과 변화를 Table 2와 Fig. 2에 나타내었다. 전자선 조사된 건오징어의 hydrocarbon류는 1-tetradecene $\left(\mathrm{C}_{14: 1}\right)$, pentadecane $\left(\mathrm{C}_{15: 0}\right)$, 1-hexadecene $\left(\mathrm{C}_{16: 1}\right)$, heptadecane $\left(\mathrm{C}_{17: 0}\right)$, 8-heptadecene $\left(\mathrm{C}_{17: 1}\right)$ 이 생성되었으며, 각각의 hydrocarbon 류의 생성량은 조사선량에 따라 유의적으로 증가하였다. 그러나 건오징어의 지방산 조성의 차이로 인하여 동일 조사 선량일지라도 hydrocarbon류의 생성량은 다르게 동정되었 다. 이는 건오징어에 감마선를 조사한 $\mathrm{Kim}$ 등(25)의 연구결 과와 유사함을 확인할 수 있었다.

Palmitic acid로부터 유도된 hydrocarbon류인 1-tetradecene $\left(\mathrm{C}_{14: 1}\right)$ 과 pentadecane $\left(\mathrm{C}_{15: 0}\right)$ 의 함량을 비교하였을 때 $\mathrm{C}_{\mathrm{n}-1}$ 

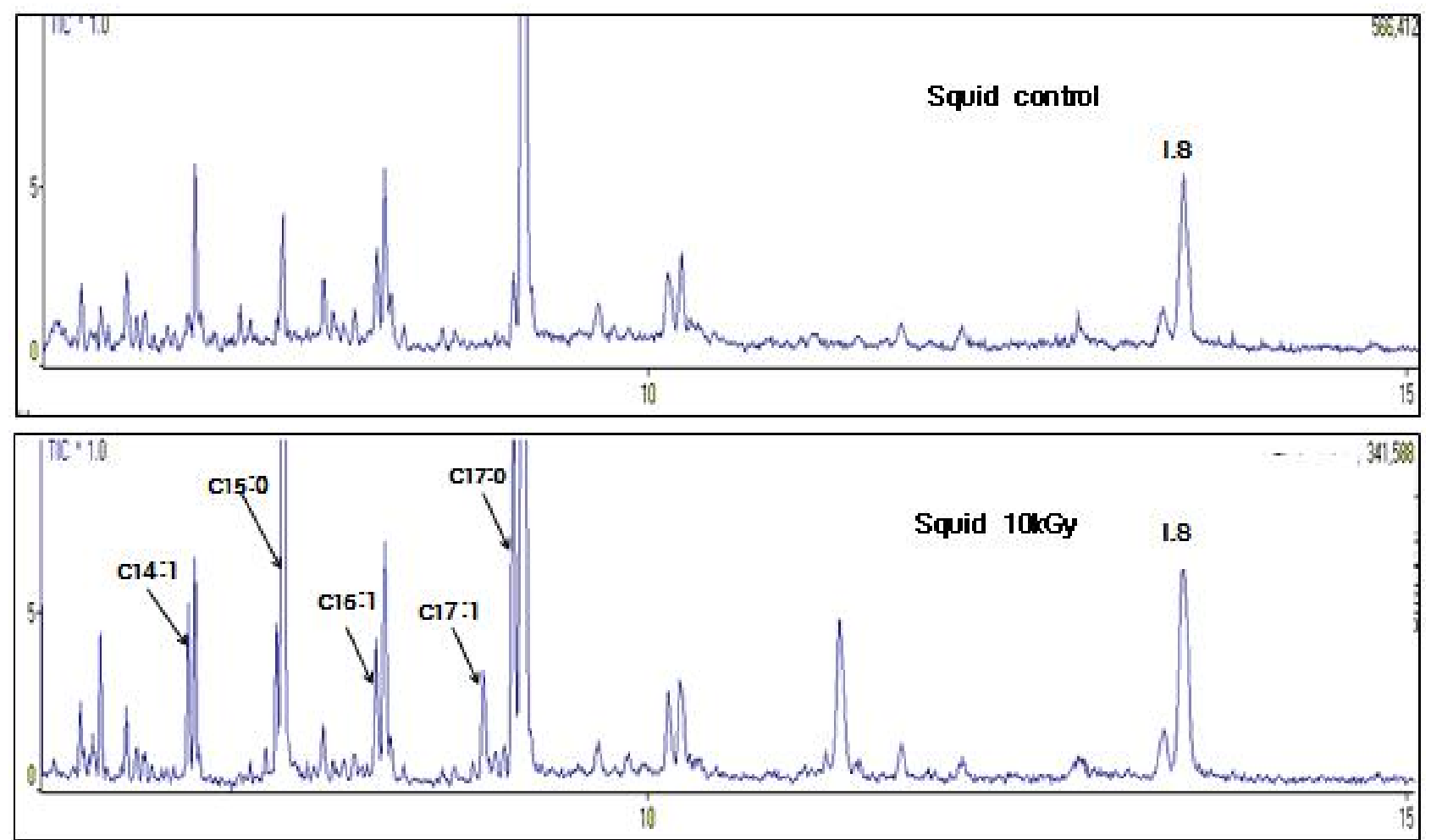

Fig. 1. GC/MS chromatograms of radiation-induced hydrocarbons in non- and $10 \mathrm{kGy}$ irradiated dried squid.

Table 2. Concentrations of radiation-induced hydrocarbons in dried squid and octopus

(1)g fat)

\begin{tabular}{|c|c|c|c|c|c|c|}
\hline \multirow[b]{2}{*}{ Samples } & \multirow{2}{*}{$\begin{array}{l}\text { Irradiation } \\
\text { Dose } \\
\text { (kGy) }\end{array}$} & \multicolumn{2}{|c|}{ Palmitic acid } & \multicolumn{2}{|c|}{ Stearic acid } & \multirow{2}{*}{$\begin{array}{c}\text { Oleic acid } \\
\text { 8-Heptadecene } \\
\left(\mathrm{C}_{17: 1}\right)\end{array}$} \\
\hline & & $\begin{array}{c}\text { 1-Tetradecene }{ }^{1)} \\
\left(\mathrm{C}_{14: 1}\right)\end{array}$ & $\begin{array}{c}\text { Pentadecane } \\
\left(\mathrm{C}_{15: 0)}\right)\end{array}$ & $\begin{array}{c}\text { 1-Hexadecene } \\
\left(\mathrm{C}_{16: 1}\right)\end{array}$ & $\begin{array}{c}\text { Heptadecane } \\
\left(\mathrm{C}_{17: 0)}\right)\end{array}$ & \\
\hline \multirow{6}{*}{$\begin{array}{c}\text { Dried squid } \\
\text { (Todarodes pacificus) }\end{array}$} & 0 & - & - & - & - & - \\
\hline & 1 & $0.75^{-22} \pm 0.05^{3)}$ & $3.36^{\mathrm{a}} \pm 0.06$ & $2.16^{\mathrm{a}} \pm 0.06$ & $1.46^{\mathrm{a}} \pm 0.06$ & $0.38^{\mathrm{a}} \pm 0.07$ \\
\hline & 3 & $1.13^{\mathrm{b}} \pm 0.05$ & $6.83^{\mathrm{b}} \pm 0.06$ & $2.74^{b} \pm 0.06$ & $2.18^{\mathrm{b}} \pm 0.12$ & $0.67^{b} \pm 0.07$ \\
\hline & 5 & $1.26^{\mathrm{c}} \pm 0.06$ & $9.96^{\mathrm{c}} \pm 0.06$ & $2.76^{b} \pm 0.06$ & $3.17^{\mathrm{c}} \pm 0.06$ & $0.94^{\mathfrak{c}} \pm 0.07$ \\
\hline & 7 & $1.93^{\mathrm{d}} \pm 0.05$ & $16.71^{\mathrm{d}} \pm 0.06$ & $2.76^{b} \pm 0.06$ & $4.30^{\mathrm{d}} \pm 0.26$ & $2.06^{\mathrm{d}} \pm 0.06$ \\
\hline & 10 & $2.15^{\mathrm{e}} \pm 0.05$ & $25.08^{\mathrm{e}} \pm 0.08$ & $3.02^{\mathrm{c}} \pm 0.04$ & $6.12^{\mathrm{e}} \pm 0.22$ & $2.27^{\mathrm{e}} \pm 0.06$ \\
\hline \multirow{6}{*}{$\begin{array}{c}\text { Dried octopus } \\
\text { (Paroctopus dofleint) }\end{array}$} & 0 & - & - & - & - & - \\
\hline & 1 & $0.46^{\mathrm{a}} \pm 0.06$ & $1.65^{\mathrm{a}} \pm 0.06$ & $2.42^{\mathrm{a}} \pm 0.05$ & $1.61^{\mathrm{a}} \pm 0.05$ & - \\
\hline & 3 & $0.91^{b} \pm 0.06$ & $2.82^{\mathrm{b}} \pm 0.05$ & $2.82^{b} \pm 0.05$ & $2.25^{b} \pm 0.06$ & - \\
\hline & 5 & $1.92^{\mathrm{d}} \pm 0.07$ & $5.09^{\mathrm{e}} \pm 0.07$ & $2.98^{\mathrm{c}} \pm 0.07$ & $2.35^{\mathrm{bc}} \pm 0.06$ & - \\
\hline & 7 & $1.89^{\mathrm{d}} \pm 0.07$ & $4.84^{\mathrm{d}} \pm 0.06$ & $3.86^{\mathrm{d}} \pm 0.06$ & $2.81^{\mathrm{d}} \pm 0.05$ & - \\
\hline & 10 & $1.74^{\mathrm{c}} \pm 0.05$ & $3.94^{\mathrm{c}} \pm 0.06$ & $3.18^{\mathrm{e}} \pm 0.07$ & $2.17^{\mathrm{b}} \pm 0.06$ & - \\
\hline
\end{tabular}

${ }^{1)}$ Radiation-induced hydrocarbons

${ }^{2) a-e}$ Concentrations with different superscripts in the same column are significantly different $(\mathrm{p}<0.05)$

${ }^{3)}$ Mean \pm standard deviation( $(\mathrm{n}=3)$.

hydrocarbon류인 pentadecane $\left(\mathrm{C}_{15: 0}\right)$ 이 $\mathrm{C}_{\mathrm{n}-2}$ hydrocarbon류인 1-tetradecene(C14:1)보다 높은 생성량을 보였다. Pentadecane $\left(\mathrm{C}_{15: 0}\right)$ 은 조사된 건오징어에서 확인된 hydrocarbon류 중 가
장 많은 생성량을 보였다. 이는 건오징어의 지방산 중 palmitic acid의 함량이 다량 존재함에 기인하였으며, 또한 용매의 간섭으로 인한 것이라고 사료되어 전자선 조사여부 


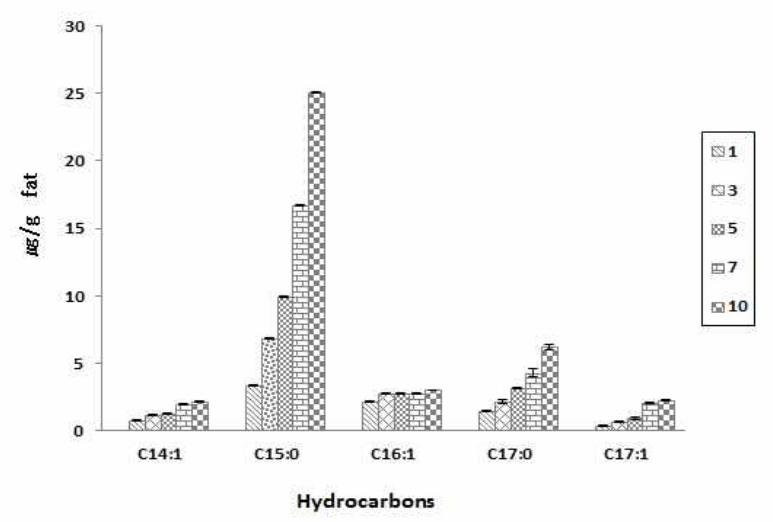

Fig. 2. Effects of irradiation dose on radiation-induced hydrocarbons from irradiated dried squid.

\section{의 판별 marker로 적합하지 않다고 판단된다.}

Stearic acid로부터 유도된 $\mathrm{C}_{\mathrm{n}-2}$ hydrocarbon류인 1-hexadecene $\left(\mathrm{C}_{16: 1}\right)$ 과 $\mathrm{C}_{\mathrm{n}-1}$ hydrocarbon류인 heptadecane $\left(\mathrm{C}_{17: 0}\right)$ 의 생성량 은 조사선량에 따라 증가하였으며, heptadecane $\left(\mathrm{C}_{1700}\right)$ 의 함 량이 1-hexadecene $\left(\mathrm{C}_{16: 1}\right)$ 보다 많아 $\mathrm{C}_{\mathrm{n}-1}$ hydrocarbon류의 생 성율이 높음을 확인하였다. 건오징어의 지방산 중 stearic acid의 함량은 palmitic acid의 $50 \%$ 미만 수준이었으나 1-hexadecene $\left(\mathrm{C}_{16: 1}\right)$ 의 함량이 1-tetradecene $\left(\mathrm{C}_{14: 1}\right)$ 보다 많아 $\mathrm{C}_{\mathrm{n}-2}$ hydrocarbon류 중 가장 높은 생성율을 보였다.

Oleic acid로부터 유도 생성되는 $\mathrm{C}_{\mathrm{n}-1}$ hydrocarbon류인 8-heptadecene $\left(\mathrm{C}_{17: 1}\right)$ 과 $\mathrm{C}_{\mathrm{n}-2}$ hydrocarbon류인 1,7-hexadecadiene $\left(\mathrm{C}_{16: 2}\right)$ 의 생성량을 비교하였을 때 8-heptadecene $\left(\mathrm{C}_{17: 1}\right)$ 의 함 량은 조사선량에 따라 증가하였으나 소량 확인되었고 1,7-hexadecadiene $\left(\mathrm{C}_{16: 2}\right)$ 은 동정되지 않았다. 이와 같은 결 과는 건오징어에 oleic acid가 매우 소량 존재하며, 또한 유통과정에서 산화에 의해 oleic acid가 파괴되어 전자선 조사에 의해 생성되어지는 1,7-hexadecadiene $\left(\mathrm{C}_{16: 2}\right)$ 의 함량 이 적거나 없기 때문이라 사료된다. 이는 Hwang 등(26)의 감마선 조사된 건오징어에서 검출된 hydrocarbon류의 연구 결과와 비슷하였다.

건오징어의 지방산 종류별 hydrocarbon류의 생성량은 대 체적으로 $\mathrm{C}_{\mathrm{n}-1}$ hydrocarbon류가 높았다. 이 결과로 hydrocarbon 류는 지방산의 $\beta$ 탄소 위치보다는 $a$ 탄소 위치에서 더 많이 생성됨을 알 수 있었다. 전자선 조사된 건오징어에서 생성 된 주요 지방분해산물인 1-tetradecene $\left(\mathrm{C}_{14: 1}\right), 1$-hexadecene $\left(\mathrm{C}_{16: 1}\right)$, heptadecane $\left(\mathrm{C}_{1700}\right), 8$-heptadecene $\left(\mathrm{C}_{17: 1}\right)$ 은 조사선량 에 따라 모두 증가하여 건오징어의 전자선 조사유무의 판별 marker 가능성을 확인하였다.

\section{전자선 조사된 건문어에서 생성되는 hydrocarbon류}

건문어의 지방산은 palmitic $\operatorname{acid}\left(\mathrm{C}_{16: 0}\right)$, palmitoleic $\operatorname{acid}\left(\mathrm{C}_{16: 1}\right)$, stearic $\operatorname{acid}\left(\mathrm{C}_{18: 0}\right), \mathrm{EPA}\left(\mathrm{C}_{20: 5}\right), \operatorname{DHA}\left(\mathrm{C}_{22: 6}\right)$ 등이 함유되어 있 었다. 그중에 포화지방산인 palmitic acid와 stearic acid 함량 이 많았으며 불포화지방산인 DHA 함량도 높았다.

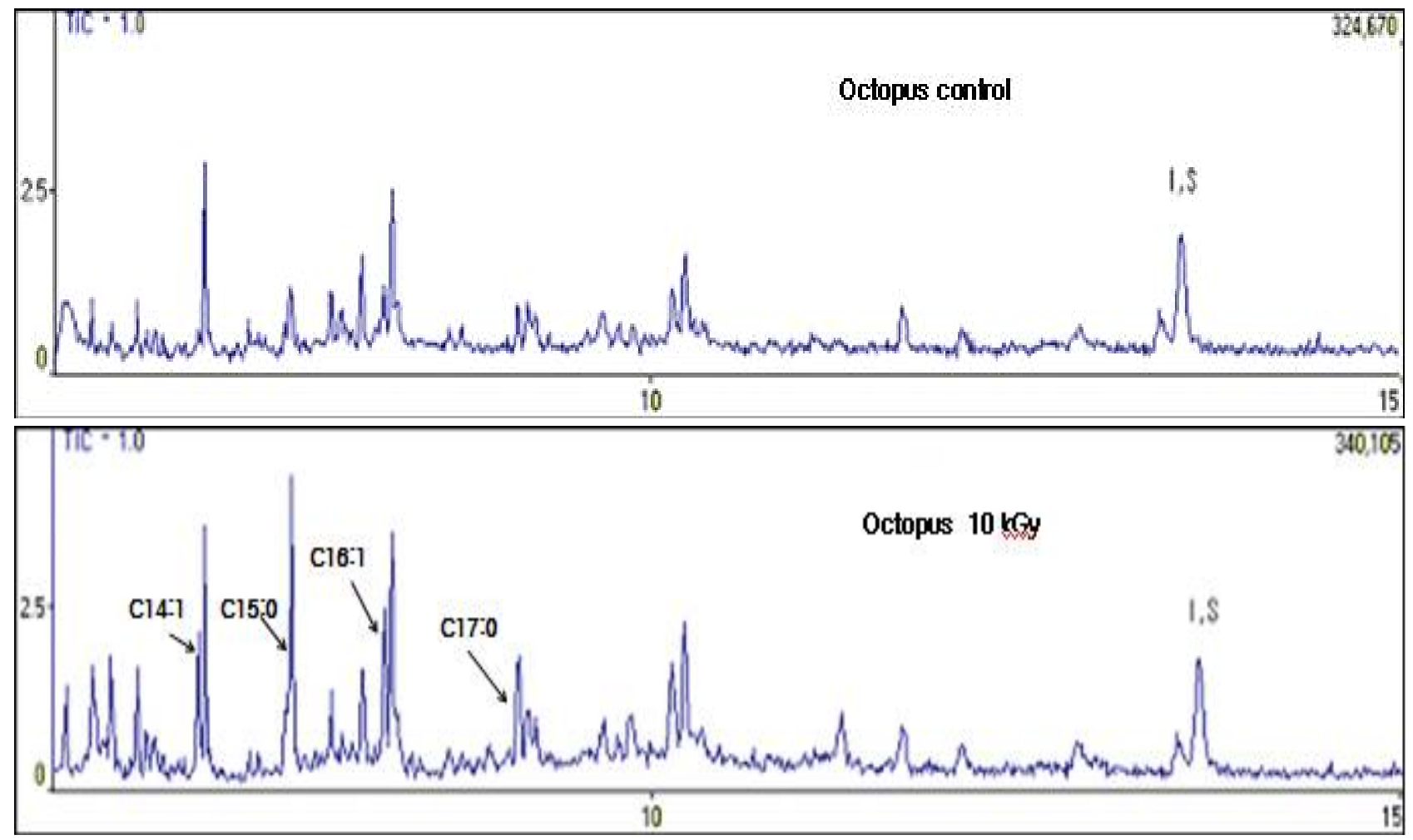

Fig. 3. GC/MS chromatograms of radiation-induced hydrocarbons in non- and $10 \mathrm{kGy}$ irradiated dried octopus. 
지방 함유 식품의 전자선 조사여부를 확인하기 위한 maker 로써 이용될 수 있는 모지방산으로 palmitic acid, stearic acid, oleic acid를 분석하였다. 건문어에서의 oleic acid는 그 함유량이 매우 낮아 oleic acid에서 유도된 hydrocarbon류 인 1,7-hexadecadiene $\left(\mathrm{C}_{16: 2}\right), 8$-heptadecene $\left(\mathrm{C}_{17: 1}\right)$ 은 분석되 지 않았다. 이는 모지방산인 oleic acid의 함량이 낮고 저장 기간 중 산화에 의해 파괴되었기 때문이라고 사료된다. Fig. 3 은 비조사 시료와 $10 \mathrm{kGy}$ 의 선량으로 조사된 건문어에서 생성된 hydrocarbon류를 GC/MS로 분석한 chromatogram이 며, 비조사 시료의 chromatogram에서 정량하기 위해 첨가 한 internal standard 외의 peak은 전자선 조사생성물인 hydrocarbon류와 시료 자체내의 화합물이 유기용매에 의해 용출된 것으로 추정되었다. Table 2에 조사 선량별로 생성 된 hydrocarbon류 함량을 나타내었으며 Fig. 4에 이를 도식 하였다. 전자선 조사에 의해 생성된 hydrocarbon류의 함량 은 지방산에 따라 큰 차이를 보였는데 palmitic acid로부터 의 pentadecane $\left(\mathrm{C}_{15: 0}\right)$ 과 1-tetradecene $\left(\mathrm{C}_{14: 1}\right)$ 의 함량은 pen tadecane $\left(\mathrm{C}_{15: 0}\right)$ 이 1-tetradecene $\left(\mathrm{C}_{14: 1}\right)$ 보다 더 많이 생성되었 다. 이들의 조사선량의 변화에 따른 생성량은 $5 \mathrm{kGy}$ 까지는 직선적으로 증가하다가 $7 \mathrm{kGy}$ 와 $10 \mathrm{kGy}$ 에서는 감소하는 경향을 보였다. 한편 stearic acid로부터 유도된 heptadecane $\left(\mathrm{C}_{170.0}\right)$ 과 1-hexadecene $\left(\mathrm{C}_{16: 1}\right)$ 의 경우 1-hexadecene $\left(\mathrm{C}_{16: 1}\right)$ 이 heptade cane $\left(\mathrm{C}_{170)}\right)$ 보다 비교적 높은 함량을 차지하였고, 조사선량 의 변화에 따른 생성량은 $7 \mathrm{kGy}$ 까지는 직선적으로 증가하 다 $10 \mathrm{kGy}$ 에서 감소되었다. 건문어의 전자선 조사에 의해 생성된 지방분해산물의 총량을 비교했을 때 건오징어의 결과와 유사하게 $\mathrm{C}_{\mathrm{n}-1}$ hydrocarbon류가 $\mathrm{C}_{\mathrm{n}-2}$ hydrocarbon류 보다 더 많이 생성되어짐을 확인하였다. 또한 모든 선량에 서 hydrocarbon류의 생성을 확인하였으며, 모지방산의 함 량에 따라 생성량이 다름을 알 수 있었다. 따라서 건문어의 전자선 조사여부를 확인하기 위한 화학적 판별법으로 GC/MS를 이용한 hydrocarbon류의 분석법이 적용 가능할 것으로 판단된다.

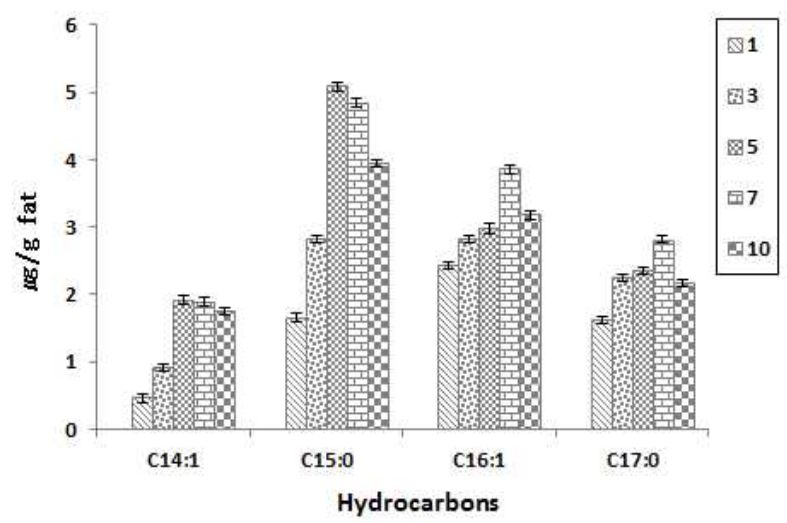

Fig. 4. Effects of irradiation dose on radiation-induced hydrocarbons from irradiated dried octopus.

\section{요 약}

식품의 방사선 조사는 식품 저장을 위한 성공적인 현대 기술의 하나이지만 매우 신중하게 이루어져야 한다. 조사 된 식품의 확인은 국제무역에서 소비자의 안전한 선택과 보호를 위해 가장 중요하다. 따라서 본 연구는 건조된 오징 어와 문어에 전자선을 조사하여 선량별로 유도 생성되는 hydrocarbon류의 함량 및 분해패턴을 확인하였다. 비조사 시료와 선량별로 전자선 조사된 시료에서 지방을 추출한 뒤 solid phase extraction(SPE) 방법을 이용하여 GC/MS로 확인하였다. 1, 3, 5, 7 및 $10 \mathrm{kGy}$ 의 선량으로 전자선 조사된 건조 오징어와 문어에서 유도된 hydrocarbon류는 동일 선 량에서 시료들의 지방산 조성에 따른 다른 생성률을 나타내 었으며, 조사선량에 따라 증가하였다. 시료들에 다량 함유 되어 있는 palmitic acid와 stearic acid로부터 생성된 1-tetradecene $\left(\mathrm{C}_{14: 1}\right)$, pentadecane $\left(\mathrm{C}_{15: 0}\right)$, 그리고 1-hexadecene $\left(\mathrm{C}_{16: 1}\right)$, heptadecane $\left(\mathrm{C}_{17: 0}\right)$ 이 전자선 조사에 의해 유도된 주 요 hydrocarbon류로 확인되었으며, 건오징어에서 hydrocarbon 류 생성량이 건문어의 hydrocarbon류 생성량 보다 더 많음 을 확인하였다. 이는 시료의 지방산 함유량에 따라 hydrocarbon류 생성량이 비례함을 알 수 있었다. 전자선 조사된 건오징어와 건문어에서 분석된 hydrocarbon류 중 1-tetradecene $\left(\mathrm{C}_{14: 1}\right)$, 1-hexadecene $\left(\mathrm{C}_{16: 1}\right)$ 그리고 heptadecane $\left(\mathrm{C}_{170}\right)$ 은 전자선 조사여부를 판별할 수 있는 지표로 활용 될 수 있을 거라 사료된다.

\section{감사의 글}

본 연구는 농림수산식품기술기획평가원(110123-03-3-HD120) 의 지원에 의해 이루어진 것이며 이에 감사드립니다.

\section{References}

1. Yang SY, Lee NH, Hong SP, Bang HA (1999) Effects of propolis treatment on the quality of dried squid. Korean J Food Sci Technol, 31, 356-360

2. Mochizuki H, Oda H, Yokogoshi H (1998) Increasing effect of dietary taurine on the serum HDL-cholesterol concentration in Rats. Biosci Biotechnol Biochem, 62, 578-579

3. Sugiyama K, Kanamori H, Takeuchi H (1992) Effect of cholesterol-loading on plasma and tissue levels in rats. Biosci Biotechnol Biochem, 56, 676-677

4. Sugiyama K, Ohishi A, Ohnua Y, Muramatsu K (1989) Comparision between the plasma cholesterol-lowring 
effects of glycine and taurine in rats fed on high cholesterol diets. Agric Biol Chem, 53, 1647-1652

5. Sakaguchi T (1989) The metabolism, biological function, and nutritional avalibility of taurine. Health Digest, 4, 1-9

6. Yim KY (1985) Sterilzation and storage of dried fishes by irradiation. Korean Home Economics Asso., 23, 37-43

7. Terashita T, Kitamoto $\mathrm{Y}$, Matsumoto $\mathrm{T}$, Hosoi N, Ichikawa Y, Kono M (1984) Nitrogen metabolism in favolus arcularius and changes in composition of free and protein amino acids during development of the mycelium and fruiting bodies. Transaction of the Mycol Soc Japan, 25, 187-198

8. Kim MJ (2000) A Study on development of hazard analysis and critical control points(haccp) model for menu using raw material from among potentially hazardous foods (PHF) in School Lunch. Ph D Thesis, Kyungsan University, Kyungsan, Korea, p 36-38

9. Byun MW (1998) Status on food irradiation in Korea J Food Sci Ind, 31, 19-24

10. IAEA (2009) International atomic energy agency homepage. www.iaea.org/icgfi.

11. Kwon JH, Byun MW, Cho HO (1992) Development of food irradiation technology and consumer attitude toward irradiation food in Korea Radioisotopes, 41, 654-662

12. Ito H, Islam $S$ (1994) Effect of does rate on inactivation of microorganism in spices by electro-beams and gamma-rays irradiation. Radiat Phys Chem, 43, 545-550

13. Lee MK, Lee MH, Kwon JH. (1998) Sterilizing effect of electron beam on ginseng powders. Korean J Food Sci Technol, 30, 1362-1366

14. Cleland MR (1983) Radiation processing: basic concepts and practical aspects. J Industr Irrad Technol, 1, 191-218

15. KFDA (2012) Standard of food and standard some revised inside administrative notice. Korea Food Drug Administration announcement, Cheongwon, Korea, p 57-58

16. Shim SL (2010) Effect of electron beam irradiation on volatile organic compounds of Vitis labrusca L. Korean
J Food Preserv, 17, 151-159

17. Hong SP, Kim EM, Yang JN, Ahni (2007) Effect of irradiation on the quality characteristics of lyophilized kimchi powder. Korean J Food Sci Technol, 39, 614-618

18. Ko JK, Ma YH, Song KB (2005) Effect of electron beam irradiation on microbial qualities of whole black pepper powder and commercial sunsik Korean J Food Sci Technol, 37, 308-312

19. Jung SME, Choe JH, Kim BN, Yun HJ, Kim YJ (2009) Micobiological, physicochemical, and sensory characteristics of myungran jeotgal treated by electron beam irradiation. Korean J Food Preserv, 16, 196-203

20. Ko JK, Ma Yhy (2005) Effect of electron beam irradiation on the microbial safety and qualities of sliced dried squid. J Korean Soc Food Sci Nutr, 34, 433-437

21. Metcalf LD, Schmitz AA, Pelka JR (1996) Rapid preparation of fatty acid esters from lipid for gas chromatographic analysis. Anal Chem, 38, 514-519

22. Lee HJ, Yun IIN, Seo HY, Song HP, Hong CH, Kim KS (2002) Analysis of Radiolytic Compounds of Lipids for the Detection of Irradiation in Dried Mytilus coruscus. J Korean Soc Food Sci Nutr, 31, 599-603

23. Kim KS, Kim EA, Lee HJ, Yang JS, Byun MW (1999) Quanititative comparison of radiation-induced hydrocarbons from irradiated beef, pork and chicken. Korean J Food Sci Technol 31, 301-307

24. Nawar WW, Champagne JR, Dubravic MF, LeTellier PR (1969) Recovery and measurement of volatiles from lipid: Hydrocarbons in irradiated fats. J Agri Food Chem, 17, 645-648

25. Kim JH, Seo HY, Kim KS (2004) Analysis of radiolytic products of lipid in irradiated dried squids(Todarodes pacificus). J Food Prot, 8, 1731-1735

26. Hwang KT, Park JY and Kim CK (1997) Application of hydrocarbons as markers for detecting post-irradiation of imported meats and fish. J Korean Soc Food Sci Nutr, 26, 1109-1115

(접수 2014년 3월 31일 수정 2014년 5월 14일 채택 2014년 5월 24일) 